\title{
PENDIDIKAN MORAL BERBASIS AGAMA FILSAFAT PSIKOLOGI DAN SOSIOLOGI
}

\author{
Huges $^{1}$, Ujang Nurjaman ${ }^{2}$ \\ ${ }^{1}$ Sekolah Pascasarjana Universitas Islam Nusantara, Bandung, Indonesia \\ Huges12@gmail.com \\ ${ }^{2}$ Sekolah Pascasarjana Universitas Islam Nusantara, Bandung, Indonesia \\ Ujangnurjaman@gmail.com
}

\begin{abstract}
Abstrak
Sentuhan aspek moral atau akhlak dan budi pekerti menjadi sangat kurang. Demikian pula, sentuhan agama yang salah satu cabang kecilnya adalah akhlak atau budi pekerti menjadi sangat tipis dan tandus. Padahal roda terus berputar dan berjalan, budaya terus berkembang, teknologi berlari sangat pesat, dan arus informasi global bagai tidak terbatas dan tidak terbendung lagi. Sebagai akibatnya adalah budaya luar yang negatif mudah terserap tanpa ada filter yang cukup kuat. Gaya hidup moderen yang konsumeristikkapitalistik dan hedonistik yang tidak didasari akhlak dan budi pekerti yang luhur dari bangsa ini cepat masuk dan mudah ditiru oleh generasi muda. Perilaku negatif, seperti tawuran, anarkis, dan cepat marah menjadi budaya baru yang dianggap dapat mengangkat jati diri mereka. Premanisme ada di mana-mana, emosi meluap-luap, cepat marah dan tersinggung, serta ingin menang sendiri menjadi bagian hidup yang akrab dalam pandangan sebagian dari diri masyarakat sendiri. Kenyataan lain juga menunjukkan adanya indikator budi pekerti dan moral yang gersang adalah banyaknya terjadi kasus pelecehan seksual yang dilakukan. Diberikannya pendidikan moral bagi anak diharapkan dapat mengubah perilaku anak, sehingga peser-ta didik jika sudah dewasa lebih bertanggung jawab dan menghargai sesamanya dan mampu menghadapi tantangan jaman yang cepat berubah. Di sinilah pentingnya nilai-nilai moral yang berfungsi sebagai media transformasi manusia Indonesia agar lebih baik, memiliki keunggulan dan kecerdasan di berbagai bidang; baik kecerdasan emosional, kecerdasan sosial, kecerdasan spiritual, kecerdasan kinestika, kecerdasan logis, musikal, linguistik, kecerdasan spasial.
\end{abstract}

Kata Kunci: Pendidikan Moral, Moral, Disiplin Ilmu

\section{PENDAHULUAN}

Sekolah merupakan sebuah lembaga yang berusaha memproses input yang berupa siswa menjadi output yang tidak hanya menguasai pengetahuan dari salah satu ranah saja, melainkan dari ketiga ranahnya yaitu kognitif, afektif dan psikomotorik secara komprehensif termasuk di dalamnya pendidikan moral. Namun kenyataannya, sering dijumpai penyimpangan perilaku siswa, yang pada akhirnya muncul adanya degradasi moral pada siswa. Sekolah akan bermakna lebih jika sudah menerapkan pendidikan moral pada siswa secara totalitas.

Keberadaan moral bagi kehidupan seseorang (pelajar) sangat penting dalam keluarga dan masyarakat. Moral pelajar yang lebih baik dalam kehidupan. Dan sebaliknya, moral pelajar yang tidak baik akan mengakibatkan suatu interaksi yang tidak harmonis dalam masyarakat yang selanjutnya akan memunculkan kegelisahan sosial.

Al Qalam: Jurnal Ilmiah Keagamaan dan Kemasyarakatan Vol. 16, No. 1

Januari - Juni 2022 
H.A.R. Tilaar mengatakan bahwa degradasi moral telah menggejala dalam kehidupan masyarakat modern dewasa ini, demikian halnya dengan para pelajar dan mahasiswa. Banyak kalangan muda atau pelajar yang melakukan tindakan-tindakan yang tidak bermoral. ${ }^{1}$

Dalam pandangan sarjanah barat seperti Pane W. Tailor, melihat moral sebagai suatu set peraturan atau standar social yang mengatur tingkah laku orang-orang di dalam suatu kebudayaan. ${ }^{2}$ Berdasarkan hal di atas berarti moral itu berkaitan dengan prinsip baik dan buruk yang diwujudkan dalam perilaku sebagai gambaran dari keadaan jiwa, tabiat seseorang; dan komponen-komponen moral setidaknya terdiri atas pertimbangan moral (keadaan batini) dan perilaku moral (keadaan lahiri). Moral manusia menurut pandangan al-Ghozali dan Ibnu Miskaway maupun Piaget dan Kohl Berg dapat dikembangkan sampai mencapai tingkat kesempurnaan. ${ }^{3}$ Untuk membentuk moral seseorang menjadi baik diperlukan serangkaian usaha-usaha konkrit, dan peran ini diambil oleh lembaga pendidikan. Dalam diri manusia terdapat dua potensi, baik dan buruk samasama baik, bahkan potensi buruk itu cenderung lebih kuat jika melihat urutan penyebutan potensi tersebut jiwa itu (jalan) kefasikan dan ketaqwaan. IIni berarti jika manusia tidak mendapatkan pendidikan (moral) maka ia cenderung akan mengikuti memenangkan potensi buruk. Oleh karena itu diperlukan pendidikan moral. ${ }^{4}$

Tugas pendidikan adalah mem Bantu anak mencapai tahap pe rkembangan moral yang tinggi (kesempurnaan moral). Dalam pandangan al-Ghozali dan Ibn Miskaway tugas pendidikan adalah membentuk anak mencapai kesempurnaan jiwa, dalam artia $\mathrm{n}$ bahwa tindakan moral yang ia lakukan sudah menyatu dalam dirinya sehingga tanpa melalui proses berfikir. ${ }^{5}$

Walaupun keduanya tidak menyebutkan tahap perkembangan secara rinci. Adapun aspek yang dibutuhkan dalam mencapai perkembangan moral tersebut adalah prinsip pembiasan (kondisioning) dan peniruan (imitation) yang mengarah pada terjadinya modeling. Pandangan ini adalah pandangan menurut al-Ghozali dan Ibn Maskaway begitu juga dengan A. Bandura, perkembangan moral tersebut berbeda dengan pandangan menurut Piaget dan Kohlberg (aliran moral relatism) yang lebih menekankan adanya keterkaitan struktur kognisi dalam perkembangan moral. Aplikasinya dalam dunia $\mathrm{p}$ endidikan dari kedua pandangan tersebut adalah diperlukan adanya cndisioning dalam mengembangkan perilaku moral seseorang.

Permasalahan pendidikan moral disekolah adalah lemahnya unsur conditioning. Dari hal

\footnotetext{
${ }^{1}$ Henry Alexis Rudolf Tilaar, Beberapa Agenda Reformasi Pendidikan Nasional Dalam Perspektif Abad 21 (Jakarta: Teras, 1998).

${ }^{2}$ Misbahus Surur, "Problematika Pendidikan Moral Di Sekolah Dan Upaya Pemecahannya," Jurnal Fikroh 4, no. 2 (2010).

${ }^{3}$ Ibid.

${ }^{4}$ Ibid., h. 126.

${ }^{5}$ Surur, "Problematika Pendidikan Moral Di Sekolah Dan Upaya Pemecahannya."
}

Al Qalam: Jurnal Ilmiah Keagamaan dan Kemasyarakatan Vol. 16, No. 1 Januari - Juni 2022 
ini akan dapat dipahami mengapa terjadi kesenjangan (dalam moralitas) antara kondisi ideal out put pendidikan dan kenyataan yang ada. Sebagaimana dijelaskan diatas bahwa pendidikan moral berupaya untuk menanamkan dan membentuk perkembangan moral anak didik dalam tahap yang sempurna. Dalam proses tersebut dibutuhkan adanya pembiasan (conditioning) terhadap tahap prilaku moral yang diajarkan dengan memberikan hadiah, pujian, penghargaan prilaku moral yang baik; dan memberi hukuman perilaku moral yang tidak baik. Dengan adanya pembiasan tersebut anak akan dibiasakan melakukan perilaku moral yang baik dengan diberi reinforcement berupa hadiah, pujian atau hal lain yang menggembirakan anak, sehingga terjadi proses internalisasi nilai moral dalam diri anak. Jika pembiasan tersebut tidak berjalan dengan baik dalam diri anak didik. Akibatnya anak didik tidak dapat mengintegrasikan nilai moral dalam perilaku moral dalam kehidupannya.

Di sekolah upaya pembiasaan dalam membentuk perilaku moral yang diharapkan kurang mendapat perhatian yang maksimal. Sebagai contoh kecil, dalam hal berdusta misalnya, pembiasaan berprilaku jujur, tidak bohong kurang mendapatkan perhatian yang serius. Guru bila menjumpai anak didik berbohong dalam suatu hal, ia cenderung menganggapnya sebagai hal yang wajar. Dalam artian tidak diberi reinforcement berupa hukuman yang keras agar anak tidak terbiasa melakukan perilaku dusta. Dari hal ini anak akan menangkap bahwa perilaku berbohong, tidak memberikan dampak yang sangat merugikan bagi dirinya, sehingga perhatian anak terhadap pembiasaan berprilaku jujur terabaikan.

Dalam hal ini faktor pemberian reinforcement (reward dan punishment) memegang peran yang penting untuk membiasakan anak melakukan tindakan moral yang baik. Dalam pemberi an reinfocement terhadap perilaku yang baik, komentar-komentar yang disampaikan guru merupakan factor penting untuk proses internalisasi atau penghayatan siswa terhadap standar moral. Faktor lain adalah pemberian teladan atau contoh dari guru dari tindakan-tindakan yang baik. Kemudian di perlukan adanya penjelasan-penjelasan terhadap pertimbangan moral (alasan-alasan melakukan komentar-komentar yang disampaikan guru merupakan factor penting untuk proses internalisasi atau penghayatan siswa terhadap standar moral. Factor lain adalah pemberian teladan atu contoh dari guru dari tindakan-tindakan yang baik. Kemudian diperlukan adanya penjelasan-penjelasan terhadap pertimbangan moral (alasan-alasan melakukan tindakan) sehingga dapat dicapai perkembangan moral pada tingkat yang tertinggi. ${ }^{6}$

Dari kedua pandangan dapat dikatakan bahwa pendidikan disatu pihak bertujuan memupuk kemampuan anak agar ia mampu mempertimbangkan moral serta dapat memberikan justifikasi moral dianggap telah siap bergerak setapak demi setapak melalui urutan tahapan yang

${ }^{6}$ Ibid., h. 1267.

Al Qalam: Jurnal Ilmiah Keagamaan dan Kemasyarakatan Vol. 16, No. 1

Januari - Juni 2022 
telah ditentukan, maka perhatian selanjutnya ditunjukkan pada cara berfikir serta system nilai yang diharapkan tidak lagi dilakukan anak dan didorong mampu melakukan pertimbangan moral baik untuk dirinya maupun untuk orang lain, sambil mengokohkan kepercayaan akan keutamaan moral yang diajarkan kemudian.

Dari uraian diatas dapat disimpulkan bahwa tugas pendidik (orang tua, guru dan sebagainya) selain memberikan pengetahuan sebanyak-banyaknya, juga membantu anak menjadi anak yang bermoral yang sempurna.

Dari latar belakang di atas, penulis tertarik untuk menyajikan makalah dengan judul: Pendidikan Moral Berbasis Agama Filsafat Psikologi Dan Sosiologi. Tujuan dari penulisan makalah ini adalah untuk mengetahuii, menganalisis dan mendapatkan informasi model kepemimpinan pendidikan masa depan berbasis agama, filsafat, psikologi, dan sosiologi.

\section{METODE PENELITIAN}

Penelitian ini menggunakan metode library research dengan jenis penelitian analisis buku dan pemikiran berbagai tokoh dalam berbagai disiplin ilmu. Tekhnik pengumpulan data dilakukan dengan mengumpulkan berbagai literature yang kemudian dianalisis menggunakan content anlysis.

\section{HASIL DAN PEMBAHASAN}

Pendidikan Moral Pendidikan moral adalah penanaman, pengembangan dan pembentukan akhlak yang mulia dalam diri anak. Pendidikan moral harus merupakan satu program atau pelajaran khusus, akan tetapi merupakan suatu dimensi dari seluruh usaha Pendidikan. ${ }^{7}$ Sedangkan menurut Nasih Ulwan mengemukakan bahwa pendidikan moral adalah sendi moral, keutamaan tingkah laku yang wajib dilakukan oleh anak didik, diusahakan dan dibiasakan sejak kecil hingga dewasa. ${ }^{8}$ Ini berarti bahwa moral seseorang itu dapat dipupuk dan dapat dikembangkan menuju tingkat perkembangan yang sempurna dalam suatu proses pendidikan.

Para psikolog seperti Pieget dan Kholberg memandang bahwa moral seseorang itu mengalami perkembangan dalam tahap-tahap operasional yang cirri-cirinya: terjadi perubahan secara bertahap kepemilikan moral. Tahap ketiga : Format operasional yang ciri-cirinya : memperimbangkan tujuan-tujuan perilaku moral, menyadari bahwa aturan moral adalah kesempatan tradisi yang berubah. ${ }^{9}$

\section{Pelaksanaan Pendidikan Moral Berbasis Agama}

\footnotetext{
${ }^{7}$ Surur, "Problematika Pendidikan Moral Di Sekolah Dan Upaya Pemecahannya."

${ }^{8}$ Abdullah Nashih Ulwan, Pendidikan Anak Menurut Islam (Pendidikan Sosial Anak) (Bandung: PT Remaja Rosdakarya, 1990).

${ }^{9}$ Muhibbin Syah, Psikologi Pendidikan (Bandung: Remaja Rosdakarya, 1995).
}

Al Qalam: Jurnal Ilmiah Keagamaan dan Kemasyarakatan Vol. 16, No. 1

Januari - Juni 2022 
Rusaknya moral seseorang anak terjadi karena dua faktor utama. Yang pertama adalah faktor keluarga dan yang kedua adalah faktor lingkungan sosialisasi. Adanya pendidikan moral sangat berperan penting dalam pembentukan generasi muda bangsa guna memiliki nilai-nilai pendidikan yang baik pada lingkungan masyarakat, khususnya lingkungan sekolah. Ini merupakan tugas pendidik menciptakan generasi-generasi bangsa yang baik, berakhlak mulia, dan berbudipekerti sesuai dengan nilai-nilai norma keagamaan. Di antara nilai-nilai yang harus ditanamkan adalah sopan santun, berbudi pekerti, berdisiplin, berhati lapang, berhati lembut, beriman dan bertakwa, berkemauan keras, bersahaja, bertanggung jawab, bertenggang rasa, jujur, mandiri, manusiawi, mencintai ilmu, menghargai karya orang lain, rasa kasih sayang, rasa malu, rasa percaya diri, rela berkorban, rendah hati, sabar, pemaaf, semangat kebersamaan, setia, sportif, taat asas, takut bersalah, tawakal, tegas, tekun, amanah, terbuka, dan ulet.

Pendidikan Moral adalah pendidikan atau usaha yang dilakukan untuk menjadikan anak manusia bermoral atau bermanusiawi. Artinya pendidikan moral adalah pendidikan yang mengajarkan tentang sikap dan bagaimana perilaku sehari-hari yang baik. Jika dalam Islam adalah Pendidikan Akhlak yaitu pendidikan yang mengajarkan tentang bagaimana seharusnya bersikap terhadap seluruh makhluk yang ada di muka bumi ini, baik yang hidup maupun mati. Fungsi dari pendidikan moral dan pendidikan akhlak adalah untuk memagari seseorang dari hal perbuatan buruk atau perbuatan tidak baik yang tidak sesuai dengan norma-norma yang ada dalam pendidikan, bermasyarakat, berbangsa, dan bernegara. ${ }^{10}$

Pendidikan moral, di zaman modern seperti sekarang ini, agaknya sudah menjadi satu fenomena kemasyarakatan yang boleh dikatakan universal. Hampir semua masyarakat modern cenderung untuk menempatkan pendidikan moral sebagai bagian integral dari sistem kependidikannya. Kendati demikian tidak lantas berarti bahwa di luar masyarakat modern tidak dikenal adanya pendidikan moral. Praksis pendidikan semacam itu sebenarnya sudah dikenal pula di berbagai tipe masyarakat, termasuk di masyarakat yang tergolong terbelakang sekalipun, yaitu dalam bentuk sosialisasi moral.

Minimnya pendidikan moral di Indonesia, mempengaruhi kemajuan Negara Indonesia, salah satunya dikarenakan adanya kecenderungan masyarakat modern untuk mulai memisahkan kehidupan keagamaannya dari aktivitas hidup kesehari-hariannya. Pendidikan berbasis moral akan sangat berguna bagi peserta didik dalam mengembangkan diri dan bergaul dengan masyarakat. Moral adalah bekal di dalam mengembangkan diri. Hal itu dikarenakan, ketika moral telah diam dalam diri, manusia akan dapat mempertanggungjawabkan segala aktivitasnya terhadap dirinya sendiri, orang lain, dan utamanya kepada Tuhan Yang Maha Esa.

\footnotetext{
${ }^{10}$ Rubini Rubini, “Pendidikan Moral Dalam Perspektif Islam,” Al-Manar 8, no. 1 (2019): h. 225.
} 
Masalah moral, adalah suatu masalah yang menjadi perhatian manusia di mana saja, baik dalam masyarakat yang telah maju, maupun dalam masyarakat yang masih terbelakang. Hal itu dikarenakan, kerusakan moral seseorang mengganggu ketentraman yang lain. Jika dalam suatu masyarakat banyak orang yang rusak moralnya, maka akan guncanglah keadaan masyarakat itu. Orang yang pendidikannya tinggi belum tentu mempunyai etika, akhlak dan moralitas yang baik. Malah banyak fakta di lapangan membuktikan betapa banyak orang yang berpendidikan tinggi memiliki kelakuan yang melanggar nilai-nilai kehidupan (agama dan moralitas) dalam bermasyarakat.

Terkadang seorang muslim bingung mencari solusi tentang masalah moral dan akhlak masyarakat. Padahal dengan merenungi dan mengaplikasikan ajaran Alquran, mereka dapat mengatasi berbagai persoalan besar dalam tubuh umat ini.

Dengan merenungkan dan mendalami makna ayat-ayat Alquran maka kita akan temukan ajaran akhlak, kasih dan cinta yang begitu dalam dan luas. Beberapa ayat Alquran yang berhubungan dengan pendidikan moral diantaranya:

1. QS.Ali Imran:200 tentang kesabaran

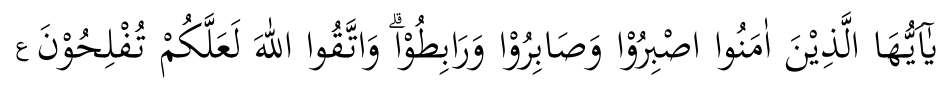

Artinya: "Wahai orang-orang yang beriman! Bersabarlah kamu dan kuatkanlah kesabaranmu dan tetaplah bersiap-siaga (di perbatasan negerimu) dan bertakwalah kepada Allah agar kamu beruntung.

2. QS.an-Nisa':58 tentang amanah

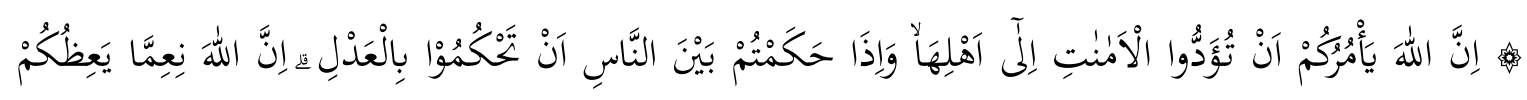

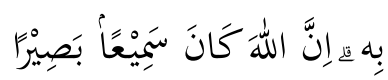

Artinya: "Sungguh, Allah menyuruhmu menyampaikan amanat kepada yang berhak menerimanya, dan apabila kamu menetapkan hukum di antara manusia hendaknya kamu menetapkannya dengan adil. Sungguh, Allah sebaik-baik yang memberi pengajaran kepadamu. Sungguh, Allah Maha Mendengar, Maha Melihat.

3. QS.al-Ma'idah:13 tentang memberi maaf

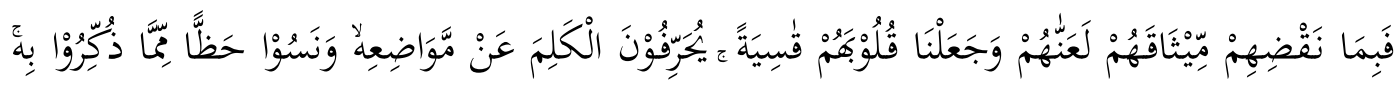

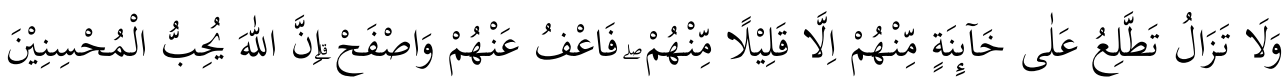

Artinya: “(Tetapi) karena mereka melanggar janjinya, maka Kami melaknat mereka, dan Kami jadikan hati mereka keras membatu. Mereka suka mengubah firman (Allah) dari tempatnya, dan mereka (sengaja) melupakan sebagian pesan yang telah diperingatkan kepada mereka. Engkau (Muhammad) senantiasa akan melihat pengkhianatan dari mereka kecuali sekelompok kecil di antara mereka (yang tidak berkhianat), maka maafkanlah mereka dan biarkan mereka. Sungguh, Allah menyukai orang-orang yang berbuat baik.

Al Qalam: Jurnal Ilmiah Keagamaan dan Kemasyarakatan Vol. 16, No. 1

$$
\text { Januari - Juni } 2022
$$


4. QS.al-Ahzab:70 tentang kejujuran

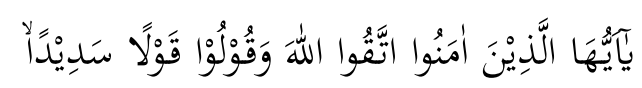

Artinya: "Wahai orang-orang yang beriman! Bertakwalah kamu kepada Allah dan ucapkanlah perkataan yang benar.

Alquran mengajarkan orang tua untuk mendidik anak menjadi generasi yang kuat, sebagaimana disebutkan dalam Surat Annisa (4:9) Dan hendaklah takut kepada Allah orang-orang yang seandainya meninggalkan di belakang mereka anak-anak yang lemah, yang mereka khawatir terhadap (kesejahteraan) mereka. Oleh sebab itu hendaklah mereka bertakwa kepada Allah dan hendaklah mereka mengucapkan perkataan yang benar."

Kita perlu mewariskan generasi yang kuat, dimulai dari anak-anak. Kuat disini mencakup empat aspek. Kuat dalam hal fisik, kuat dalam hal ilmu, kuat dalam hal iman (tidak musyrik) dan kuat dalam hal karakter atau akhlak. Anak-anak perlu kita beri makan yang bergizi baik, perlu diberikan makanan ilmu pengetahuan yang setinggi-tingginya, perlu diajari mengenai mengikis kemusyrikan dalam dirinya dan orang lain (ingat musyrik kepemilikan, pengabdian, aturan, perlindungan/perilaku dan figur!), perlu diajari akhlak dan karakter yang sesuai dengan Alquran.

Tujuan mendidik anak adalah agar mereka dapat menjadi generasi yang menjadi pemimpin atau imam bagi orang yang bertakwa, sebagaimana disebutkan dalam Surat Al Furqan (25:74), Dan orang orang yang berkata: "Ya Tuhan kami, anugrahkanlah kepada kami isteri-isteri kami dan keturunan kami sebagai penyenang hati (kami), dan jadikanlah kami imam bagi orangorang yang bertakwa.

Menjadikan anak sebagai imam bagi orang-orang bertakwa berarti mendidik anak menjadi anak yang bertakwa terlebih dahulu, yaitu manusia yang selalu bersegera mohon ampun, bersedekah dalam kondisi lapang dan sempit, menahan amarah, memaafkan orang lain dan berbuat baik Surat Ali Imran (3:133-134). Urgensi akhlak dalam Islam hadir dalam bentuk disiplin ilmu tersendiri, yaitu ilmu akhlak.

\section{Pelaksanaan Pendidikan Moral Berbasis Filsafat}

Secara etimologis, moral berasal dari bahasa Latin moralis-mos, moris. Bentuk Jamaknya adalah mores yang diartikan adat istiadat, watak, tingkah laku, akhlak, cara hidup. Sedangkan dalam pengertian terminologis, moral diartikan sebagai sesuatu yang menyangkut kegiatan-kegiatan manusia yang dipandang sebagai baik atau buruk, benar atau salah, dan tepat atau tidak tepat. Secara sederhana diartikan bahwa moralitas merupakan suatu code of conduct (kode etik) atau sistem nilai yang memberi petunjuk tentang perbuatan benar dan salah maupun nafsu, keinginan, keyakinan,

Al Qalam: Jurnal Ilmiah Keagamaan dan Kemasyarakatan Vol. 16, No. 1

Januari - Juni 2022 
tuturkata, sifat, karakter dan lain sebagainya yang berhubungan dengan tindakan. ${ }^{11}$

Di dalam perilaku moral, faktor terpenting adalah bagaimana daya-daya manusia berperan menurut proporsi masing-masing melalui pemberdayaan peran akal semaksimal mungkin. Hanya akal sempurna aktivitasnyalah yang dapat menjaga keselarasan dan keharmonisan hubungan dayadaya jiwa. Sedangkan untuk memungkinkan manusia menyukai dan melakukan perbuatan moral, perlu adanya kesadaran diri. Akal, hati dan kesadaran diri adalah segi-segi eksistensi manusia yang original yang memiliki peranan penting dalam perwujudan perilaku moral.

Mengenai pentingnya kesadaran ini dalam perilaku manusia Poudjawijatna mengatakan bahwa kesadaran moral berarti kesadaran manusia untuk selalu berbuat baik. Oleh karena itu, moral dapat menjadi tuntunan atau pedoman manusia, di samping juga menjadi pengarah bagi terwujudnya perbuatan. Moral mengarahkan manuisa untuk bertingkah laku baik, dan manusia sendiri pada dasarnya juga memiliki kecenderungan yang baik.

Berbeda dengan penjunjung relativisme, Gilbert Harman, bahwa moralitas harus bergantung pada beberapa hukum sosial yang diperkuat oleh adat-istiadat dan tekanan sosial. Harman berpendapat bahwa moralitas berasal dari kaidah atau adat-istiadat yang dijalankan oleh masyarakat dalam hal tertentu. Benar dan salah tidak ditentukan oleh keputusan dan prinsip individu tertentu, melainkan didasarkan atas kaidah dan adat-istiadat yang dilaksanakan secara sosial. Setiap agama mengandung ajaran moral yang menjadi pegangan bagi penganutnya. Misalnya hukum halal dan haram, puasa, ibadah, dan lain sebagainya. Mahmud Syaltut menyatakan bahwa "agama adalah ketetapan Ilahi yang diwahyukan kepada Nabi-Nya untk menjadi pedoman hidup manusia". ${ }^{12}$

Sementara itu, Syaikh Muhammad Abdullah Bardan berupaya menjelaskan arti agama dengan merujuk pada Alquran dengan melalui pendekatan kebahasaan. Emmanuel Kant mengatakan bahwa agama adalah perasaan tentang wajibnya melaksanakan perintah-perintah Tuhan. Harun Nasution berpandangan agama adalah kepercayaan terhadap Tuhan sebagai suatu kekuatan gaib yang memengaruhi kehidupan manusia sehingga melahirkan cara hidup tertentu. Sejalan dengan itu, Endang Saifuddin Ansari mengatakan agama adalah sistem kredo (tata ritus, tata peribadatan), sistem norma yang mengatur hubungan manusia dengan sesamanya dan alam sekitarnya berdasarkan sistem keimanan dan sistem peribadatan. Berdasarkan pengertian di atas, dapat disimpulkan bahwa agama adalah kebiasaan atau tingkah laku manusia yang didasarkan pada jalan peraturan atau hukum Tuhan yang setimpal atau adil berupa pahala. Dan apabila tidak ditaati ia akan memperoleh balasan yang setimpal atau adil pula berupa azab atau hukuman dari Tuhan.

Moral juga disinonimkan dengan etiket. Etiket artinya lebih menitikberatkan pada cara-

\footnotetext{
${ }^{11}$ Howard J Curzer, Ethical Theory and Moral Problems (California: Wadsworth Publishing, 1999), h. 6.

${ }^{12}$ M. Quraish Shihab, Membumikan Al Qur'an: Peran Wahyu Dalam Kehiduan Masyarakat (Bandung: Mizan, 2003), h. 209.
}

Al Qalam: Jurnal Ilmiah Keagamaan dan Kemasyarakatan Vol. 16, No. 1 Januari - Juni 2022 
cara berbicara yang sopan, cara berpakaian, cara duduk, cara menerima tamu di rumah, dimanapun dan sopan santun lainnya. Etiket ini sering disebut pula tata krama. Etiket tidak menentukan perbuatan mana yang benar, melainkan perbuatan manakah yang sopan.

\section{Pelaksanaan Pendidikan Moral Berbasis Psikologi}

Moralitas merupakan seperangkat aturan yang apabila ditaati oleh setiap orang maka akan meningkatkan Human Flourishing. (Perkembangan Manusia). Peraturan ini memang membatasi kebebasan kita tetapi sejatinya untuk meningkatkan kebebasan dan kesejahteraan yang lebih besar lagi. secara lebih spesifik pojman menguraikan lima tujuan moralitas: ${ }^{13}$

1. Mencegah masyarakat dari perpecahan.

2. Memperbaiki penderitaan manusia dan menjadikan hidupnya lebih baik.

3. Meningkatkan perkembangan manusia (memungkinkan orang untuk mencapai potensipotensi mereka untuk hidup yang bahagia).

4. Menyelesaikan perselisihan yang didasari oleh kepentingan.

5. Memberi pujian atau menyalahkan, memberi penghargaan atau hukuman dan rasa bersalah Dalam kajian psikologi, filsafat dan etika, banyak muncul perdebatan tentang arti moralitas, sehingga sulit menemukan konsensus definisi moralitas (lihat tabel 1 untuk berbagai definisi moralitas). Menurut Jonathan Haidt, moralitas adalah segala sesuatu yang berkaitan dengan penekanan keinginan diri dalam rangka memunculkan kerjasama.

Dalam melakukan perilaku moral, manusia biasanya menggunakan berpikir atau menalar tindakannya. Secara umum, ada dua cara penalaran moral dalam perspektif etika normatif: berpikir tentang konsekuensi dan berpikir tentang batasan perilaku.

Penalaran etika normatif pertama adalah kita berbuat baik karena akan menghasilkan kebaikan dan manfaat pada orang yang lebih luas (pendekatan konsekuensiatau utilitarian). Salah satu tokohnya Jeremy Bentham. Maka sebelum membuat perilaku moral, manusia harus mempertimbangkan apa dampak tindakan pada orang lain, bukan hanya pada diri sendiri. Proses pertimbangan ini lebih dipandu oleh intuisi atau apa yang "dirasa" benar atau baik oleh seseorang bukan berdasarkan kontrol penalaran. Misalkan: ketika akan membeli jam tangan mewah, orang perlu bertanya moralitas tindakannya. Apakah uang yang digunakan untuk membeli jam lebih memberikan kebaikan pada orang banyak? Ataukah harusnya ia memberikan uang tersebut untuk donasi ke orang miskin. Seorang moralis konsekuensi akan memilih memberikan uangnya untuk donasi karena akan memberikan kebaikan pada orang yang lebih banyak.

Pemikiran moralis konsekuensi ini bisa jadi unggul untuk memberikan dampak positif pada

${ }^{13}$ Al-Hasan Al-Aidaros and Faridahwati Mohd Shamsudin, "Ethics and Ethical Theories From an Islamic Perspective," International Journal of Islamic Thought 4 (2013): h. 3.

Al Qalam: Jurnal Ilmiah Keagamaan dan Kemasyarakatan Vol. 16, No. 1 Januari - Juni 2022 
masyarakat luas, namun juga bisa muncul permaslahan ketika prinsip moral hilang karena selalu mempertimbangkan dampak pada orang kebanyakan. Misalkan: pemerkosaan adalah salah, baik bagi korban karena dirugikan dan juga pelaku karena telah melanggar peraturan. Namun, prinsip moral bisa bengkok jika kebanyakan masyarakat berpikir bahwa pemerkosaan bukanlah masalah jika korban pemerkosaan justru berperilaku mengundang pemerkosaan (ie. pakai baju yang tidak menutup semua tubuh dan keluar malam tanpa pendampingan laki-laki) dan aksi pemerkosaan yang dilakukan oleh pelaku hanyalah perilaku seks untuk mendapatkan kepuasan.

Pendekatan etika normatif kedua adalah deontologi, yang menyatakan semua tindakan memiliki batasan moral. Deontologi berseberangan dengan konsekuensialis, perilaku moral diletakkan dalam keharusan melakukan kewajiban untuk menegakkan kebenaran demi kewajiban itu sendiri; bukan demi untung-rugi, diterima atau ditolak oleh masyarakat, dan juga bukan untuk mendapatkan kesenangan atau kesusahan. Tindakan moral dibatasi oleh serangkaian peraturan yang lahir dari proses berpikir rasional dan intelek manusia, yaitu: rasionalitas (akal sehat digunakan untuk membuat argumen moral), dan mempromosikan nilai-nilai kebenaran universal (misalkan: kemanusiaan, hormat pada manusia).

Salah satu tokoh moralis deontology adalah Imanuel Kant. Dalam pendekatan ini, perilaku moral perlu lahir dari proses berpikir mengenai apa motif serta dampak universal suatu perilaku. Misalkan: apakah saya perlu berbohong? Jika moralis konsekuensi akan mempertimbangkan dampak berbohong (akan berbohong jika akan menyelamatkan orang lain atau membuat keadaan tidak menjadi lebih buruk), sedangkan moralis deontologi akan berpikir secara intelek apakah berbohong memiliki keterbatasan moral. Deontologis akan bertanya bagaimana jika semua orang di dunia berbohong? maka akan terjadi kekacauan dan masalah. Oleh karena itu semua orang seharusnya jangan berbohong walaupun akibat bercerita yang sebenarnya bisa menyakitkan atau merugikan. Moralis deontologi akan berargumen bahwa pertimbangan moralitas seharusnya bukan diletakkan pada konsekuensi tindakan, tapi pada motif tindakan itu sendiri. Perilaku moral harus berdasarkan rasional yang benar. Namun, deontologi bisa memiliki kelemahan, kadang peraturan yang dipilih untuk membatasi perilaku manusia tidak melulu hasil kreasi rasionalitas, tapi bisa juga produk emosi subyektif seseorang yang telah dirasionalisasi. Dalam hal ini bisa terjadi adu argumen dan rasionalisasi.

Emosi, atau perasaan dan intuisi, memainkan peran utama dalam sebagian besar proses pengambilan keputusan moral manusia. Kebanyakan orang tidak menyadari betapa emosi mereka mengarahkan pilihan moral mereka. Perasaan yang ditimbulkan oleh penderitaan, seperti simpati dan empati, sering menuntun orang untuk bertindak moral terhadap orang lain. Intuisi manusia dituntun oleh emosi dalam menentukan benar dan salah, sangat rentan dipengaruhi oleh emosi yang dirasakan manusia. Sebagai contohnya: jika anda membaca berita dan melihat foto-foto tentang 
pembantaian suku bangsa atau genosida, apa intuisi moral yang muncul? Biasanya orang akan menyatakan tindakan genosida adalah salah, tanpa banyak penalaran; dan kita bisa merasakan emosi yang terbangun di tubuh kita serta terbentuknya intusi moral negatif terhadap genosida. David Hume mengatakan bahwa kebanyakan pemahaman dan keputusan moral manusia bukan didasari oleh penalaran, melainkan hasrat manusia. Akibatnya, tindakan moral manusia tidak akan pernah murni hasil penalaran, tapi adalah suatu hasil keputusan yang dinalar setelah ditentukan oleh intuisi dan emosi. ${ }^{14}$

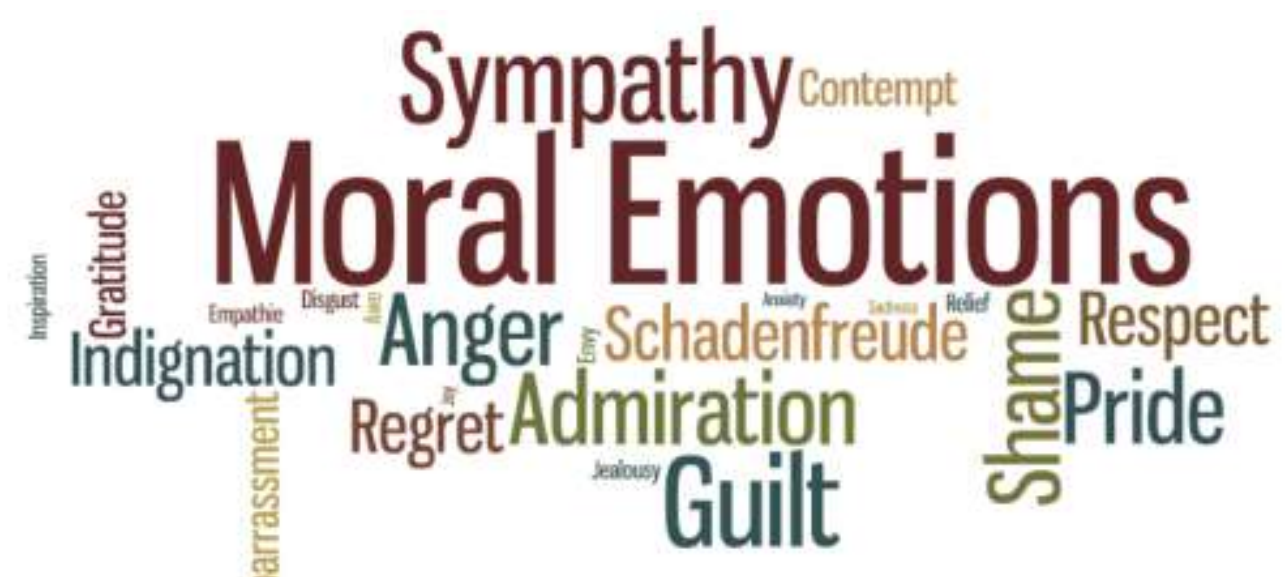

Gambar: Emosi Moral

\section{Pelaksanaan Pendidikan Moral Berbasis Sosiologi}

Persoalan moral selalu menjadi wacana yang menarik dan tak pernah gersang untuk ditelaah dalam setiap pemikiran tentang baik dan buruk perilaku manusia. Baik buruk suatu perilaku manusia mengarah pada setiap tindakan yang senantiasa dilakukannya. Di mana perbuatan akan dikatakan bermoral jika tindakannya sesuai dengan aturan, sebaliknya perbuatan akan dianggap buruk atau tidak bermoral apabila tindakannya tidak sesuai aturan. Pembahasan mengenai perilaku manusia dalam kehidupan sehari-hari seringkali disebut dengan istilah "etika" atau moral. Etika pada umumnya diidentikan dengan moral (moralitas). Istilah moral berasal dari kata latin mores, bentuk jamak dari mos, yang berarti adat istiadat, watak, kelakuan. ${ }^{15}$

Keduanya memiliki arti yang sama, perbedaannya hanya terletak pada kedua asal kata itu. Etika merupakan cabang aksiologi yang pada pokoknya membicarakan masalah "benar" (right) dan "salah" (wrong) dalam arti "susila" (moral) dan "asusila" (immoral).

Menurut Drs. Wahyudi Kumorotomo dalam bukunya yang berjudul Etika Administrasi

14 Jonathan Haidt, "The Moral Roots of Liberals and Conservatives. TED Talk," http://www. ted. com/talks/lang/en/jonathan_haid_on_the_moral_mind.html (2008).

${ }^{15}$ Yoanisa Mahardiani and Ari Pradhanawati, "Pengaruh Stres Kerja Dan Lingkungan Kerja Fisik Terhadap Kinerja Karyawan Outsourcing Pada PT. Bank Jateng Cabang Koordinator Dan Cabang Pembantu Wilayah Kota Semarang," Jurnal Administrasi Bisnis 2, no. 1 (2013).

Al Qalam: Jurnal Ilmiah Keagamaan dan Kemasyarakatan Vol. 16, No. 1

Januari - Juni 2022 
Negara mengatakan bahwa etika adalah ilmu pengetahuan tentang kesusilaan atau moral. Sedangkan moral adalah hal-hal yang mendorong manusia untuk melakukan tindakan-tindakan yang baik sebagai kewajiban atau norma.

Moralitas merupakan seperangkat aturan yang apabila ditaati oleh setiap orang maka akan meningkatkan human flourishing. Perkembangan manusia). Peraturan ini memang membatasi kebebasan kita tetapi sejatinya untuk meningkatkan kebebasan dan kesejahteraan yang lebih besar lagi.

Secara lebih spesifik pojman menguraikan lima tujuan moralitas: ${ }^{16}$

1. Mencegah masyarakat dari perpecahan.

2. Memperbaiki penderitaan manusia dan menjadikan hidupnya lebih baik.

3. Meningkatkan perkembangan manusia (memungkinkan orang untuk mencapai potensipotensi mereka untuk hidup yang bahagia).

4. Menyelesaikan perselisihan yang didasari oleh kepentingan.

5. Memberi pujian atau menyalahkan, memberi penghargaan atau hukuman dan rasa bersalah.

Dalam kehidupannya, manusia senantiasa berperilaku baik (manusiawi) bahkan yang terbaik guna mencapai tujuan hidup yaitu kebahagiaan. Namun, seringkali seseorang melakukan perbuatan baik hanya didasarkan untuk mendapatkan pujian dari orang lain, tanpa didasari dengan rasa ikhlas ataupun atas dasar kewajiban berbuat baik. Berkaitan dengan tingkah laku dalam kehidupan bersama, manusia harus memperhatikan kepentingan moral dalam diri manusia yang didasari oleh suatu kebajikan yang tinggi yang bersumber dari dalam diri manusia itu sendiri, yaitu dengan memperhatikan kepentingan orang lain. ${ }^{17}$

Sebagai makhluk sosial, manusia tidak dapat hidup tanpa bantuan orang lain dan tidak bisa mengandalkan hidup sendiri. Oleh karena itu, manusia selalu memadukan kontak dengan manusia lainnya agar tidak terjadi kekacauan dalam kehidupan bermasyarakat, segala tindakan manusia yang satu dengan yang lain harus dilandasi dengan kode etik dan secara konkret diatur oleh norma-norma hukum tertentu. Oleh karena itu, permasalahan mengenai moral tidak luput pembahasannnya dari konteks sosiologis.

Emile Durkheim merupakan salah satu tokoh sosiologi abad pertengahan yang hidup di masa peralihan dan suasana krisis yang sedang melanda Eropa. Di mana pada masa itu bangsa Eropa sedang mengalami kemerosotan moral. Maka Durkheim berusaha mencari suatu alternatif lain untuk dapat menyatukan masyarakat Prancis melalui suatu pendidikan moral. Lebih dari itu, Durkheim adalah pemikir yang sangat bercorak sosiologistik dan tanpa henti ingin mendapatkan

16 Al-Aidaros and Mohd Shamsudin, "Ethics and Ethical Theories From an Islamic Perspective," h. 3. 17 Ayi Sofyan, Kapita Selekta Filsafat (Bandung: Pustaka Setia, 2010), h. 357.

Al Qalam: Jurnal Ilmiah Keagamaan dan Kemasyarakatan Vol. 16, No. 1 Januari - Juni 2022 
"ilmu moralitas" yang bersifat deduktif, obyektif, rasional, dan positivistis. ${ }^{18}$

Durkheim berargumen, dengan adanya suatu pendidikan moral maka masyarakat di Prancis dapat memadu kehidupan sosial mereka. Selain itu, cita-cita Durkheim untuk membentuk suatu masyarakat yang damai, teratur, dan bebas konflik akan mudah tercipta dengan sendirinya. Sehingga sangatlah jelas, Durkheim memandang pengajaran moralitas umum bagi warga di masa mendatang dalam tahun-tahun pembentukannya merupakan hal yang sangat penting untuk memperkuat dasar-dasar masyarakat dan meningkatkan integrasi serta solidaritas sosialnya.

\section{KESIMPULAN DAN SARAN}

Moral adalah bekal dalam mengembangkan diri. Masalah moral, adalah masalah yang menjadi perhatian manusia di mana saja, baik dalam masyarakat yang telah maju, maupun dalam masyarakat yang masih terbelakang. Hal itu dikarenakan, kerusakan moral seseorang mengganggu ketenteraman yang lain. Jika dalam masyarakat banyak orang yang rusak moralnya, maka guncanglah keadaan masyarakat itu. Pendidikan moral bagi anak dapat mengubah perilaku anak, sehingga jika sudah dewasa lebih bertanggung jawab dan menghargai sesamanya dan mampu menghadapi tantangan jaman yang cepat berubah. Peningkatan pertimbangan moral pada diri anak yang dirancang melalui pendidikan di sekolah, dapat membantu pembentukan kepribadian anak, karena dengan terbentuknya pertimbangan moralnya, anak akan berperilaku sesuai dengan cara berpikir moral yang ada padanya.

Tiga unsur yang ditetapkan oleh Durkheim, untuk bisa menjadi pribadi yang bermoral yang pertama adalah disiplin; kedua adalah keterikatan pada kelompok; ketiga adalah otonomi. Ketiga unsur ini dibutuhkan setiap individu untuk bisa menjadi pribadi yang bermoral. Dan tindakan moral pada hakikatnya merupakan fokus sentral dari dunia moral, yang akan membentuk kepribadian yang bertanggung jawab, disiplin, serta menjadi pribadi yang baik dalam lingkungan masyarakat, dan menghindari perilaku yang tidak baik, sesuai dengan cara berpikir moral yang telah diberikan.

Sekolah perlu melakukan pedagogi kritis. Subyek didik perlu dilatih berpikir kritis. Dalam era teknologi informasi dan komunikasi sekarang ini, tiap hari, melalui berbagai media komunikasi, baik cetak maupun elektronik, kita dibanjiri oleh berbagai informasi dan pesan (termasuk iklaniklan yang mendorong orang untuk menjadi konsumeris) yang mau mengatakan kepada kita apa yang perlu dilakukan dan apa yang perlu dihindari, apa yang perlu dipercayai serta apa yang perlu dicurigai.

18 Ari Basuki, "Perbandingan Antara Pemikiran Karl Marx Dengan Pemikiran J. Krishnamurti Tentang Perubahan Sosial," Humaniora 20, no. 3 (2008): 306-314.

Al Qalam: Jurnal Ilmiah Keagamaan dan Kemasyarakatan Vol. 16, No. 1

Januari - Juni 2022 
Pendidikan nilai kebenaran dan kejujuran, di tengah meluasnya kebohongan publik, di antaranya iklan-iklan konsumeris serta dominasi budaya pasar yang begitu mendewakan nilai uang dan sukses duniawi sampai menghalalkan segala cara untuk dapat cepat kaya, hidup enak dan berkuasa, tentu saja menjadi suatu kegiatan yang melawan arus. Pendidikan bertujuan bukan hanya membentuk manusia yang cerdas otaknya dan trampil dalam melaksanakan tugas, namun diharapkan menghasilkan manusia yang memiliki moral, sehingga menghasilkan warga negara yang baik. Oleh karena itu pendidikan tidak semata-mata mentransfer ilmu pengetahuan kepada peserta didik, tetapi juga mentransfer nilai-nilai moral dan nilai-nilai kemanusiaan yang bersifat universal.

\section{DAFTAR PUSTAKA}

Al-Aidaros, Al-Hasan, and Faridahwati Mohd Shamsudin. "Ethics and Ethical Theories From an Islamic Perspective." International Journal of Islamic Thought 4 (2013): 1-13.

Basuki, Ari. "Perbandingan Antara Pemikiran Karl Marx Dengan Pemikiran J. Krishnamurti Tentang Perubahan Sosial." Humaniora 20, no. 3 (2008): 306-314.

Curzer, Howard J. Ethical Theory and Moral Problems. California: Wadsworth Publishing, 1999.

Haidt, Jonathan. "The Moral Roots of Liberals and Conservatives. TED Talk." http://www. ted. com/talks/lang/en/jonathan_haid_on_the_moral_mind.html (2008).

Mahardiani, Yoanisa, and Ari Pradhanawati. "Pengaruh Stres Kerja Dan Lingkungan Kerja Fisik Terhadap Kinerja Karyawan Outsourcing Pada PT. Bank Jateng Cabang Koordinator Dan Cabang Pembantu Wilayah Kota Semarang.” Jurnal Administrasi Bisnis 2, no. 1 (2013).

Rubini, Rubini. "Pendidikan Moral Dalam Perspektif Islam.” Al-Manar 8, no. 1 (2019): 225-271.

Shihab, M. Quraish. Membumikan Al Qur'an: Peran Wahyu Dalam Kehiduan Masyarakat. Bandung: Mizan, 2003.

Sofyan, Ayi. Kapita Selekta Filsafat. Bandung: Pustaka Setia, 2010.

Surur, Misbahus. "Problematika Pendidikan Moral Di Sekolah Dan Upaya Pemecahannya." Jurnal Fikroh 4, no. 2 (2010).

Syah, Muhibbin. Psikologi Pendidikan. Bandung: Remaja Rosdakarya, 1995.

Tilaar, Henry Alexis Rudolf. Beberapa Agenda Reformasi Pendidikan Nasional Dalam Perspektif Abad 21. Jakarta: Teras, 1998.

Ulwan, Abdullah Nashih. Pendidikan Anak Menurut Islam (Pendidikan Sosial Anak). Bandung: PT Remaja Rosdakarya, 1990.

Al Qalam: Jurnal Ilmiah Keagamaan dan Kemasyarakatan Vol. 16, No. 1 Januari - Juni 2022 